\title{
Translation and Validation of the Indonesian Version of the Hypertension Knowledge-level Scale
}

\author{
lin Ernawati*, Selly Septi Fandinata, Silfiana Nisa Permatasari \\ Clinical Pharmacy Department, Pharmacy Faculty, Airlangga University, Surabaya, Indonesia
}

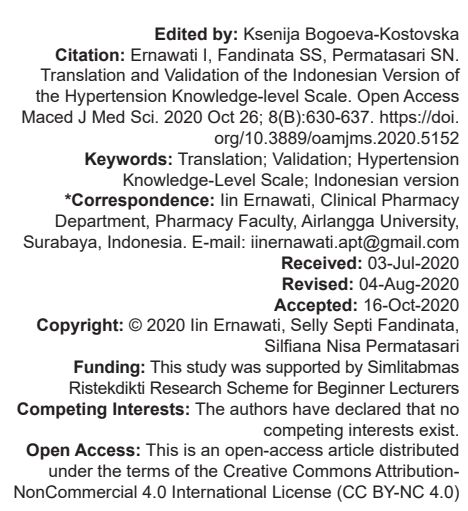

\section{Introduction}

Hypertension is a disease that has risk factors for cardiovascular disease [1]. Hypertension is a chronic disease with an increase in arterial blood pressure [2]. The diagnosis of hypertension is made on twice measurements with intervals of $5 \mathrm{~min}$ in a state of rest/ calm, and it is considered as hypertension if the systolic blood pressure (SBP) is $\geq 140 \mathrm{mmHg}$ and the diastolic blood pressure (DPB) pressure is greater than or equal to $90 \mathrm{mmHg}$ in patients without diabetes. Meanwhile, the SBP is $\geq 130 \mathrm{mmHg}$ and DPB is $\geq 80 \mathrm{mmHg}$ in patients with diabetes [3]. Based on JNC 8, therapeutic output in the age group $\geq 60$ years, the blood pressure value is $<150 / 90 \mathrm{mmHg}$, while in the age group $<60$ years, the blood pressure value is $<140 / 90 \mathrm{mmHg}$ [4].

Hypertension is able to cause complications such as chronic kidney disease, heart disease, and stroke [1]. At present, hypertension is a big challenge in Indonesia because it is often found in primary health care. Based on a national basic health research survey in 2013, the incidence of hypertension in Indonesia was ranked 6 out of 10 categories of chronic non-communicable diseases. The prevalence of hypertension in Indonesia, according to national basic health research in 2018 , increased from $25.8 \%$ to $34.1 \%$. Based on these data, it is very important to increase knowledge and understanding of hypertension in terms of disease, treatment, and lifestyle so that it is expected to provide increasing adherence in consuming drugs and implementing a healthy life. One way to increase understanding is to increase patient and community knowledge about hypertension. A study about knowledge stated that poor knowledge and lack of confidence of patients in the treatment of hypertension were one of the factors that affected the quality of life of patients [5]. The knowledge included the acquisition of information and skills gained from learning and experience [6].

Research from Turkey by Erkoc et al. [7] developed the hypertension knowledge level scale (HK-LS) questionnaire to measure/evaluate the level of adherence regarding hypertension. The original version of this questionnaire was published in English in 2012 and had been translated and used in several countries. HK-LS is used in several countries, including Iran, to measure the knowledge of hypertension, treatment, and control of hypertension [8]. Translation and cultural adaptation were able to be done when using 
instruments from different countries [9]. HK-LS had been translated into Arabic to measure the adherence of hypertensive patients [6]. The HK-LS instrument had also been adapted in Greek by Chatziefstratiou et al. [10], Polish by Jankowska-Polanska [8], and in Brazilian by Arthur et al. [9]. As far as the researchers concerned, no one had developed the Indonesian version of the HK-LS questionnaire. The purpose of this study was to translate and evaluate the validity and reliability of the HK-LS (Hypertension Knowledge-Level Scale) so that it could be adapted or used in Indonesia. The development of the Indonesian version of the HK-LS instrument was used to assess respondents' knowledge in understanding what is meant by hypertension, lifestyle, medical care, medication compliance, and hypertension complications.

\section{Participants and Methods}

\section{Participants}

Participants in this study were hypertension patients and non-hypertension individuals from five community health center in Surabaya, Indonesia. In this study, HK-LS instruments were translated into Bahasa and were validated and tested for reliability; patients medical records, inform consent, and respondent consent were the subject of the study.

\section{Methods}

This HK-LS translations and validation study was conducted in May 2020. The subjects of this study were adult hypertension patients ( $\geq 20$ years) from five community health centers in Surabaya, Indonesia. Before the validation test, a pre-test was conducted on 30 respondents, while for the validation and reliability test was for 185 respondents of hypertensive patients and 56 non-hypertensive individuals who were following the inclusion and exclusion criteria. The questionnaire was given online through a link (Google form) or link sent directly to the patient's phone number or WhatsApp application, which had previously been explained about matters relating to the study, on respondents who are willing to participate in this research. This study had received ethical worth from the Ethics Committee of the Faculty of Public Health, Airlangga University, with number: 100/EA/KEPK/2020.

\section{Inclusion criteria}

1. Patients receiving antihypertensive drugs (hypertensive patients) and non-hypertensive individuals with age $\geq 20$ years

2. Indonesian citizen
3. Having the ability to understand and use the Bahasa fluently

4. Having the ability to read

5. Willing to be contacted by telephone or text message for the research process.

\section{Exclusion criteria}

1. Pregnant woman

In this study, researchers had received permission from the author of the HK-LS instrument, the English version of Erkoc et al. [7], to carry out language transfer and validation into Bahasa. Based on Erkoc et al. [7], consisting of 22 statements which were divided into six sub-dimensions, namely:

Definitions
Medical treatment
Drug adherence
Lifestyle
Diets
Complications

$$
\begin{aligned}
& : \text { Items } 1 \text { and } 2 \\
& : \text { Items } 6,7,8, \text { and } 9 \\
& : \text { Items } 3,4,5, \text { and } 12 \\
& : \text { Items } 10,11,13,16, \text { and } 17 \\
& : \text { Items } 14 \text { and } 15 \\
& : \text { Items } 18,19,20,21, \text { and } 22
\end{aligned}
$$

Each statement was designed with an answer Likert-style scale, with three answer choices which are "true," "false," and "do not know." The maximum score was 22 , where the score was obtained when the respondent answered all statements correctly [8].

The translation process was adapted to international guidelines [11], [12]. Recommended language transfer stages included in the study:

\section{Initial translation (forward translation)}

The HK-LS instrument in this study was translated by two translators. The first translator was from a health professional who was familiar with the terminology area discussed in the HK-LS instrument, understood the culture and native language of the instrument (English), and target language (Indonesian language/Bahasa). This initial translation process conducted by translators of a health professional who had lived in English-speaking countries and had experienced developing questionnaires, but the native language is Bahasa. The second translator was a translator who had lived in English-speaking countries but non-health professionals.

\section{Expert panel}

This process was carried out to discuss the results of the forward translation.

\section{Back translation}

This process was the process of re-translating the HK-LS instrument from Bahasa to the native language of the instrument (English). Backward translation was done by two translators, including one translator was from the observed instrument area and one independent (sworn) translator.

\section{Expert committee \\ The results of forwarding and backward translation were discussed with expert panels. They}


were two translators, two pharmacists, and one clinician to obtain the final translated version of the instrument which was correct semantically, idiomatically, and conceptually.

\section{Pre-testing}

This step was the first step in testing. In this study, the testing was conducted on 30 (consist of male and female) respondents of hypertensive patients who were willing to take this pre-test and came from different socioeconomic groups. From this pre-test, it was seen that if some difficult words were not equivalent in meaning between the source language and target language in the translated questionnaires, the researchers replaced the words in the Indonesian version that has equivalent meaning with the original instrument.

6. The final version of validity and reliability (use instrument in target language)

The final results of the translation were tested for validity and reliability. In this study, the construct validity test was carried out through statistical methods and discriminative validity. Replenishment of reliability was done through internal testing, testretest reliability.

\section{Statistical analytics}

a) Test the Pearson correlation product-moment validity

b) Internal consistency.

Cronbach alpha coefficients were measured to determine instrument reliability.

c) Test-retest reliability.

Test-retest reliability was to assess how stable the instrument to be used at different times. In this study, the test-reliability test was conducted on the same respondent in 2 weeks after the first instrument was given. Spearman rank correlation coefficient was used to assess the level of acceptance between tests and re-tests.

d) Discriminative validity.

Discriminative validity in this study compared the two HKLS group scores of hypertensive and nonhypertensive subjects [7], [10]. It was conducted by comparing scores between groups of subjects with hypertension and non-hypertension. Statistical analysis in this study used SPSS 23 software

\section{Results}

\section{Sample}

The sociodemographic characteristic of this research showed in Figures 1 and 2.

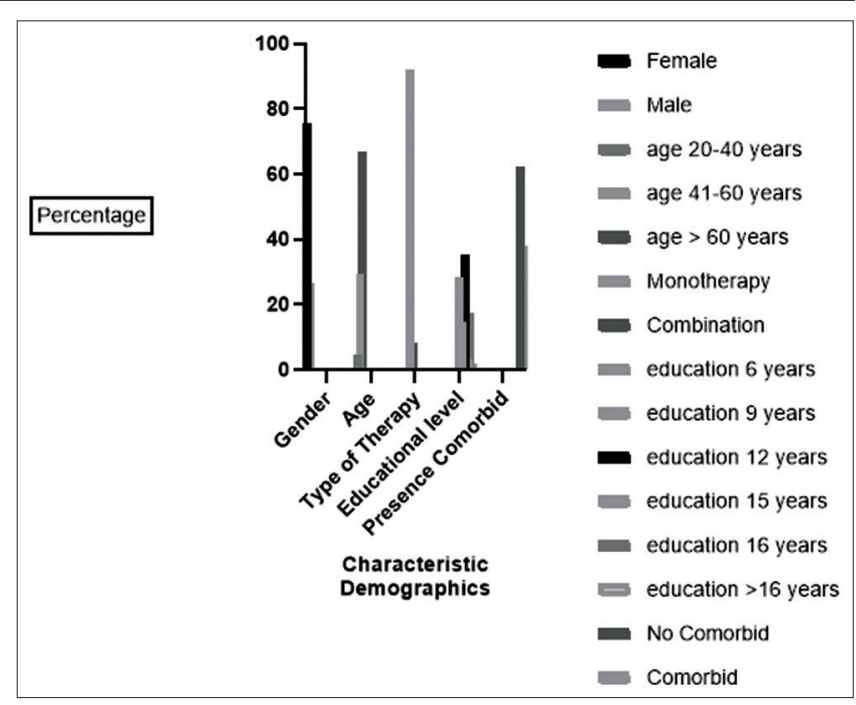

Figure 1: Percentage of baseline characteristic in hypertension patients

\section{Hypertensive sample}

The sociodemographic characteristics of each sample showed in Figure 1.

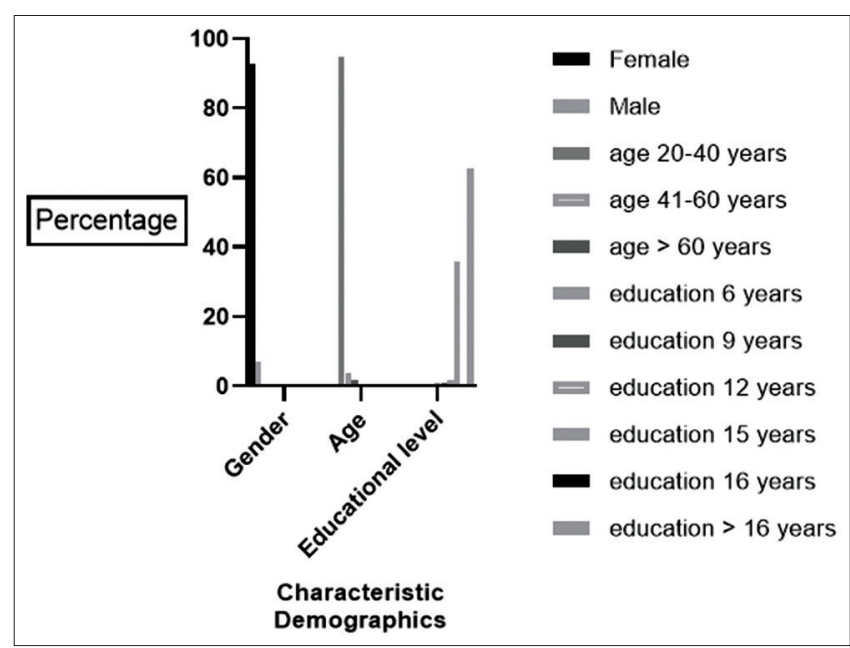

Figure 2: Baseline characteristic of non-hypertensive individuals

\section{Non-hypertensive sample}

The sociodemographic characteristics of each non-hypertensive sample is showed in Figure 2.

\section{Concurrent validity}

The validity test of the Pearson product-moment correlation used the principle of correlating or linking each statement item score with the total score of respondents' answers to the questionnaires. Statement items were stated valid if the value of the Pearson product-moment correlation ( $r$ ) was greater than the $r$ table calculated in the Pearson correlation [13]. R table for the number of hypertensive samples $185(\mathrm{n})$ was equal to 0.2632 and $r$ table for the number of non-hypertensive subjects 56 
Table 1: Pearson correlation product moment

\begin{tabular}{|c|c|c|c|}
\hline $\begin{array}{l}\text { Sub-dimension } \\
\text { item }\end{array}$ & $\begin{array}{l}\text { Pearson correlation } \\
\text { hypertension samples } \\
\text { ( } r \text { count) }\end{array}$ & $\begin{array}{l}\text { Pearson correlation } \\
\text { non-hypertension } \\
\text { samples } \\
\text { ( } r \text { count) }\end{array}$ & $\begin{array}{l}\text { Validity with } R \text { table } \\
\text { hypertensive samples } 185(n) \\
(0.2632) \text { non-hypertensive } \\
\text { samples } 56(n)(0.1443) \\
\text { valid ( } r \text { table }<r \text { count) }\end{array}$ \\
\hline \multicolumn{4}{|l|}{ Definition } \\
\hline 1. Tekanan darah tinggi diastolik atau sistolik mengindikasikan peningkatan tekanan darah. & 0.348 & 0.646 & Valid \\
\hline 2. Tekanan darah diastolik yang meningkat juga mengindikasikan peningkatan tekanan darah. & 0.307 & 0.603 & Valid \\
\hline Medical treatment & & & Valid \\
\hline $\begin{array}{l}\text { 3. Individu dengan tekanan darah yang meningkat harus minum obat, karena anda percaya itu } \\
\text { adalah cara yang terbaik }\end{array}$ & 0.273 & 0.603 & Valid \\
\hline 4. Obat untuk tekanan darah yang meningkat harus diminum setiap hari & 0.328 & 0.642 & Valid \\
\hline $\begin{array}{l}\text { 5. Individu dengan tekanan darah yang meningkat harus minum obat mereka hanya ketika } \\
\text { mereka merasa sakit. }\end{array}$ & 0.529 & 0.512 & Valid \\
\hline 6. Individu dengan tekanan darah yang meningkat harus minum obat sepanjang hidupnya. & 0.479 & 0.533 & Valid \\
\hline Drug compliance & & & Valid \\
\hline 7. Tekanan darah yang adalah hasil dari penuaan, jadi perawatan tidak perlu dilakukan. & 0.383 & 0.467 & Valid \\
\hline $\begin{array}{l}\text { 8. Jika obat untuk tekanan darah yang meningkat dapat mengontrol tekanan darah, maka tidak } \\
\text { perlu mengubah gaya hidup }\end{array}$ & 0.393 & 0.393 & Valid \\
\hline $\begin{array}{l}\text { 9. Jika individu dengan tekanan darah yang meningkat mengubah gaya hidup mereka, maka } \\
\text { tidak perlu perawatan }\end{array}$ & 0.441 & 0.733 & Valid \\
\hline $\begin{array}{l}\text { 10. Individu dengan tekanan darah yang meningkat dapat makan makanan asin selama mereka } \\
\text { minum obat secara teratur }\end{array}$ & 0.367 & 0.383 & Valid \\
\hline Lifestyle & & & Valid \\
\hline $\begin{array}{l}\text { 11. Untuk individu dengan tekanan darah yang meningkat, metode memasak terbaik adalah } \\
\text { menggoreng. }\end{array}$ & 0.428 & 0.433 & Valid \\
\hline $\begin{array}{l}\text { 12. Untuk individu dengan tekanan darah yang meningkat, metode memasak terbaik adalah } \\
\text { merebus atau memanggang. }\end{array}$ & 0.349 & 0.621 & Valid \\
\hline 13. Individu dengan tekanan darah yang meningkat harus sering makan buah dan sayuran & 0.285 & 0.354 & Valid \\
\hline 14. Individu dengan tekanan darah yang meningkat tidak boleh merokok. & 0.350 & 0.349 & Valid \\
\hline 15. Individu dengan tekanan darah yang meningkat dapat minum minuman beralkohol. & 0.277 & 0.330 & Valid \\
\hline Diet & & & Valid \\
\hline $\begin{array}{l}\text { 16. Jenis daging terbaik untuk individu dengan tekanan darah yang meningkat adalah daging } \\
\text { merah (sapi, kambing) }\end{array}$ & 0.181 & 0.371 & Valid \\
\hline $\begin{array}{l}\text { 17. Jenis daging terbaik untuk individu dengan tekanan darah yang meningkat adalah daging } \\
\text { putih (unggas) }\end{array}$ & 0.244 & 0.495 & Valid \\
\hline Complications & & & Valid \\
\hline 18. Tekanan darah yang meningkat dapat menyebabkan stroke, jika tidak ditangani & 0.475 & 0.278 & Valid \\
\hline $\begin{array}{l}\text { 19. Tekanan darah yang meningkat dapat menyebabkan penyakit jantung, seperti serangan } \\
\text { jantung, jika tidak ditangani. }\end{array}$ & 0.408 & 0.341 & Valid \\
\hline 20. Tekanan darah yang meningkat dapat menyebabkan kematian dini jika tidak ditangani. & 0.537 & 0.622 & Valid \\
\hline 21. Tekanan darah yang meningkat dapat menyebabkan gagal ginjal, jika tidak ditangani. & 0.305 & 0.603 & Valid \\
\hline $\begin{array}{l}\text { 22. Tekanan darah yang meningkat dapat menyebabkan gangguan penglihatan, jika tidak } \\
\text { ditangani. }\end{array}$ & 0.417 & 0.644 & Valid \\
\hline
\end{tabular}

(n) was equal to 0.1443 (95\% confidence interval). The value of $r$ count Pearson correlation of each item HK-LS statement was more than $r$ table; this showed that each item HKLS statement was valid (Table 1).

\section{Internal consistency}

The Cronbach alpha coefficient in this study was 0.758 hypertensive samples and 0.858 nonhypertensive samples $(p<0.05)$, with Cronbach alpha values per item HK-LS instrument, showed in Table 2.

\section{Test-retest reliability}

The results of the test-retest reliability HKLS score of hypertensive patients from the first and second reliability testing had a positive correlation. Spearman's test resulted in correlation analysis, obtained $r$ was equal to 0.890 , while non-hypertensive respondents obtained $r$ was equal to 0.96 ( $p<0.05)$. Scatter plot of the HK-LS test and re-test scores showed in Figure 3.

\section{Discriminative validity}

Discriminative validity in this study compared two groups of HK-LS scores, the hypertensive and nonhypertensive respondent groups. From the results of the Mann-Whitney test conducted, it obtained a MannWhitney value of 3805 with $p<0.05$.

\section{Discussion}

According to the study of Sharma et al. [14], a patient's ability to adhere to disease management guidelines depends on the patient's educational background and information about disease management. Respondent's knowledge was influenced by many factors such as experience and information facilities. Furthermore, knowledge of hypertension affects the success of the treatment. It involves several nonpharmacological approaches such as dietary adjustments, physical exercise, and blood pressure monitoring [14]. Knowledge of hypertension can affect blood pressure control, such as knowledge on blood pressure target management, dietary habit, lifestyles, exercise, salt intake, complications, and hypertension treatment [15]. Good knowledge of hypertension would affect patient adherence in taking medications. It would affect the patient's blood pressure so that complications, such as coronary heart disease and chronic renal disease, do not occur in the patient. This disease can be prevented when risk factors are controlled. Meanwhile, prevention is 
Table 2: Cronbach alpha items of HKLS

\begin{tabular}{|c|c|c|c|}
\hline $\begin{array}{l}\text { Sub-dimension } \\
\text { item }\end{array}$ & $\begin{array}{l}\text { Cronbach Alpha per items HK-LS } \\
\text { Hypertensive samples }\end{array}$ & $\begin{array}{l}\text { Cronbach Alpha per items HK-LS } \\
\text { Non- Hypertensive samples }\end{array}$ & $\begin{array}{l}\text { Reliability (Cronbach } \\
\text { alpha }>0.7 \text { ) }\end{array}$ \\
\hline \multicolumn{4}{|l|}{ Definition } \\
\hline $\begin{array}{l}\text { 1. Tekanan darah tinggi diastolik atau sistolik mengindikasikan peningkatan } \\
\text { tekanan darah. }\end{array}$ & 0,76 & 0.846 & Reliable \\
\hline $\begin{array}{l}\text { 2. Tekanan darah diastolik yang meningkat juga mengindikasikan peningkatan } \\
\text { tekanan darah. }\end{array}$ & 0.765 & 0.849 & Reliable \\
\hline \multicolumn{4}{|l|}{ Medical treatment } \\
\hline $\begin{array}{l}\text { 3. Individu dengan tekanan darah yang meningkat harus minum obat, karena anda } \\
\text { percaya itu adalah cara yang terbaik }\end{array}$ & 0.739 & 0.849 & Reliable \\
\hline 4. Obat untuk tekanan darah yang meningkat harus diminum setiap hari & 0.754 & 0.847 & Reliable \\
\hline $\begin{array}{l}\text { 5. Individu dengan tekanan darah yang meningkat harus minum obat mereka } \\
\text { hanya ketika mereka merasa sakit. }\end{array}$ & 0.744 & 0.852 & Reliable \\
\hline $\begin{array}{l}\text { 6. Individu dengan tekanan darah yang meningkat harus minum obat sepanjang } \\
\text { hidupnya. }\end{array}$ & 0.751 & 0.852 & Reliable \\
\hline \multicolumn{4}{|l|}{ Drug compliance } \\
\hline $\begin{array}{l}\text { 7. Tekanan darah yang adalah hasil dari penuaan, jadi perawatan tidak perlu } \\
\text { dilakukan. }\end{array}$ & 0.747 & 0.854 & Reliable \\
\hline $\begin{array}{l}\text { 8. Jika obat untuk tekanan darah yang meningkat dapat mengontrol tekanan } \\
\text { darah, maka tidak perlu mengubah gaya hidup }\end{array}$ & 0.732 & 0.856 & Reliable \\
\hline $\begin{array}{l}\text { 9. Jika individu dengan tekanan darah yang meningkat mengubah gaya hidup } \\
\text { mereka, maka tidak perlu perawatan }\end{array}$ & 0.752 & 0.843 & Reliable \\
\hline $\begin{array}{l}\text { 10. Individu dengan tekanan darah yang meningkat dapat makan makanan asin } \\
\text { selama mereka minum obat secara teratur }\end{array}$ & 0.748 & 0.858 & Reliable \\
\hline \multicolumn{4}{|l|}{ Lifestyle } \\
\hline $\begin{array}{l}\text { 11. Untuk individu dengan tekanan darah yang meningkat, metode memasak } \\
\text { terbaik adalah menggoreng. }\end{array}$ & 0.756 & 0.855 & Reliable \\
\hline $\begin{array}{l}\text { 12. Untuk individu dengan tekanan darah yang meningkat, metode memasak } \\
\text { terbaik adalah merebus atau memanggang. }\end{array}$ & 0.755 & 0.848 & Reliable \\
\hline $\begin{array}{l}\text { 13. Individu dengan tekanan darah yang meningkat harus sering makan buah dan } \\
\text { sayuran }\end{array}$ & 0.758 & 0.856 & Reliable \\
\hline 14. Individu dengan tekanan darah yang meningkat tidak boleh merokok. & 0.758 & 0.857 & Reliable \\
\hline $\begin{array}{l}\text { 15. Individu dengan tekanan darah yang meningkat dapat minum minuman } \\
\text { beralkohol. }\end{array}$ & 0.761 & 0.858 & Reliable \\
\hline \multicolumn{4}{|l|}{ Diet } \\
\hline $\begin{array}{l}\text { 16. Jenis daging terbaik untuk individu dengan tekanan darah yang meningkat } \\
\text { adalah daging merah (sapi, kambing) }\end{array}$ & 0.746 & 0.859 & Reliable \\
\hline $\begin{array}{l}\text { 17. Jenis daging terbaik untuk individu dengan tekanan darah yang meningkat } \\
\text { adalah daging putih (unggas) }\end{array}$ & 0.765 & 0.854 & Reliable \\
\hline \multicolumn{4}{|l|}{ Complications } \\
\hline 18. Tekanan darah yang meningkat dapat menyebabkan stroke, jika tidak ditangani & 0.746 & 0.860 & Reliable \\
\hline $\begin{array}{l}\text { 19. Tekanan darah yang meningkat dapat menyebabkan penyakit jantung, seperti } \\
\text { serangan jantung, jika tidak ditangani. }\end{array}$ & 0.744 & 0.857 & Reliable \\
\hline $\begin{array}{l}\text { 20. Tekanan darah yang meningkat dapat menyebabkan kematian dini jika tidak } \\
\text { ditangani. }\end{array}$ & 0.736 & 0.848 & Reliable \\
\hline $\begin{array}{l}\text { 21. Tekanan darah yang meningkat dapat menyebabkan gagal ginjal, jika tidak } \\
\text { ditangani. }\end{array}$ & 0.737 & 0.849 & Reliable \\
\hline $\begin{array}{l}\text { 22. Tekanan darah yang meningkat dapat menyebabkan gangguan penglihatan, } \\
\text { jika tidak ditangani. }\end{array}$ & 0.732 & 0.847 & Reliable \\
\hline
\end{tabular}

a mandatory effort in maintaining independent health. To support this, it is necessary to test individual knowledge of hypertension. It needs to develop an instrument to improve understanding of hypertension from both the things needed to be done and avoided (poor lifestyle) as well as adherence to the consumption of antihypertensive drugs in hypertensive patients. Management and control of hypertension are very possible, with a combination of treatments and lifestyle changes [14].

Qualitative adherence measurement can be taken as an initial screening of the adherence level of hypertensive patients. It is not only carried out to check drug-taking behavior but also used to assess beliefs and barriers related to adherence [16]. One of the qualitative method approaches is a questionnaire, which is cheap, feasible, easy to use, and reliable [17]. Therefore, the improved instrument in this research is a questionnaire used to assess the level of knowledge of hypertension to be given a change/intervention on the knowledge. Based on the research done by Nadeem et al. [18], knowledge of qualified hypertension is able to improve blood pressure control. Other studies stated that a low level of knowledge triggered the nonadherence of hypertensive patients to consume the hypertension drugs [19].
This study aimed to translate and validate the HK-LS Indonesian version. The translation process for the Indonesian version of the HK-LS questionnaire used the international guidelines recommended by the World Health Organization [12]. Among them, through the forward/initial translation stage which was carried out by at least two independent translators who have the same mother tongue as the target language. The second stage is the expert panel discussion stage, which is the stage to discuss the translation results of the initial translation. The third stage is the backward translation, where the questionnaire was translated back from the target language (Bahasa) to the original language of the questionnaire (English). This stage aimed to find out whether there is a difference in the meaning of the translated language (Indonesian as the target language) and the meaning of each questionnaire item in the original language (English). In this stage, it was found words or sentences that are not clear at the initial translation stage. The choice of words on the questionnaire was adapted to the culture of the target language. The fourth stage is the expert committee. The stage of discussion was conducted between experts who have been experienced in translation and questionnaire development. As the result, the final translation was deemed correct according 
HK-LS Score Distribution

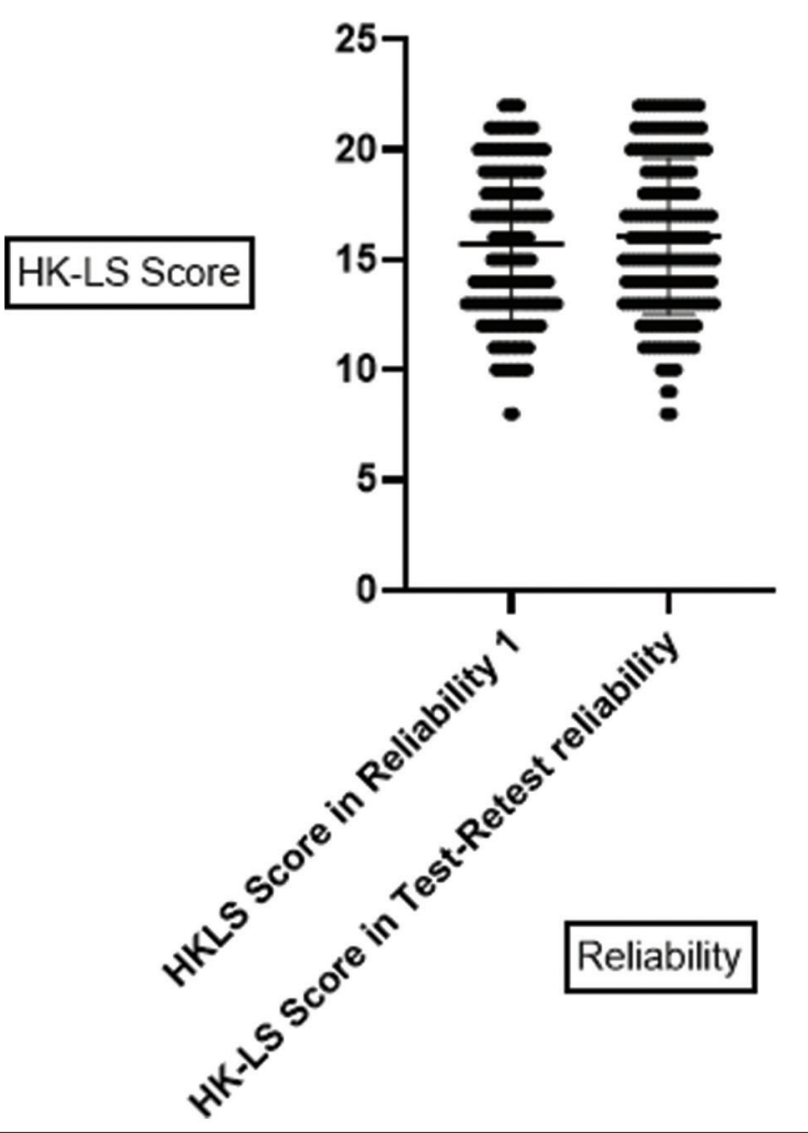

Figure 3: Test and re-test score HK-LS hypertension and nonhypertension samples

to the target culture and language [12]. The next stage was the pre-testing stage, which is the stage of testing the translation result questionnaire from the results of the expert committee discussion.

The most critical process in the translation process is the pre-test process because in this process the choice of words and sentences used was noticed whether it was correct or not. The pre-test process is very important to see if the grammatical improvement and selection of words were appropriate to the culture and the understanding of patients [20]. The next stage is the questionnaire validation process. This stage is to see statistically whether the translated questionnaire is valid and reliable [12].

The translation and validation methods in this study were used to ensure the selection of correct and comprehensive words and sentences. In fact, the results showed that this instrument is usable and understandable [9]. To assure if a questionnaire containing valid and reliable statement items of measurement of behavior or knowledge, validation process is worth conducted [20]. Meanwhile, to assess the consistency of survey results, a reliability test was also taken place. This test needs to be done to check whether errors in sampling, changes in respondents, and differences between the raters exist. The reliability or consistency of the questionnaire can be evaluated using internal consistency, test-retest reliability, and inter-rater reliability, respectively [20]. This study carried out test and re-test reliability to see whether the questionnaire gave relatively consistent results between different time measurements for each individual [21], [22]. The Indonesian version of the validation and reliability process of HK-LS was followed by 241 respondents consisting of 185 hypertensive patients and 56 nonhypertensive patients with demographic characteristics showed in Figure 1 and Figure 2. The majority of hypertensive respondents who participated in this study were $75.51 \%$ female; gender also influenced knowledge because females have ways of thinking and acting as well as focus on addressing problems [23]. Meanwhile, the age group of $>60$ years reached $66.48 \%$. Age is also one of the factors affecting the patient's knowledge of a healthy lifestyle. Most of those who suffered from hypertension were caused by unhealthy eating patterns [24]. Furthermore, educational background happens to be one of the causes, where those that received formal education for 12 years were at most $35.13 \%$. Patients without co-morbidities had the highest percentage $(62.16 \%)$. The co-morbid disease found was diabetes mellitus, heart disease, and stroke. The majority of non-hypertensive patients was women and those who did not have a history of co-morbid disease.

Furthermore, the results of the validity and reliability test can also be used to assess the possibility and feasibility of this instrument for the next target population. Another validity test was to use Pearson correlation product moment, which compared the correlation value of each item of instrument statement with the total of all statement items, where all statement items were valid with $r$ tests in hypertensive patients for all instrument items between 0.181 and 0.537 . Meanwhile, for non-hypertensive patients, it was known that the $r$ test obtained was between 0.278 and 0.733 . Pearson product-moment correlation value of 2 groups was more than $r$ table. This showed that each item of the HK-LS questionnaire statement is valid.

Internal consistency in this study was to see how reliable HK-LS instrument items are able to be used. Instrument items are said to be reliable and accepted if the value of the alpha Cronbach coefficient is $\geq 0.6(p<0.05)$. Based on the results of the reliability test, it was known that the alpha Cronbach total of all instrument items in hypertensive patients was 0.758 and non-hypertension was 0.858 . The Cronbach alpha of each HK-LS instrument item is listed in Table 2. These results were different from the original version of Erkoc et al. [7], which reached 0.82. However, this result showed that the questionnaire is reliable and able to be used in the target population in Indonesia.

Test-retest reliability was done to give the same questionnaire to the same respondent at different 
times. The higher the correlation value, the higher the level of reliability is. Re-test reliability was done after 2 weeks of performing a reliability test to the same respondent. Comparing the results of the HKLS score between reliability 1 and re-test reliability (2) using the Spearman Rank Correlation analysis obtained in hypertensive patients, the value of $r$ was equal to 0.890 and non-hypertension obtained $r$ was equal to 0.965 ( $p$ $<0.05$ ). These results confirmed that HK-LS instrument items could be used for the target group in Indonesia.

Discriminative validity in this study was carried out by comparing the two groups of HK-LS scores of hypertensive patients with co-morbidities and without co-morbidities. The discriminative validity test used the Mann-Whitney test of 3805 with $p<0.05$. It indicates that there were significant differences between the two groups of HK-LS scores. The weakness of this study was the limited respondents. In the future, this study can be used as part of the initial research, after which further research could be done to see the level of knowledge about hypertension and the factors that influenced the level of knowledge.

\section{Conclusion}

Based on translation and validation, it was known that the Indonesian version of HK-LS was valid and reliable for the target population of hypertensive patients so that this instrument was able to be used such as in community health centers, hospitals, and the general public.

\section{References}

1. World Health Organization. A Global Brief on Hypertension: Silent Killer, Global Public Health Crises (World Health Day 2013). Geneva: World Health Organization; 2013.

2. Ampofo AG, Khan E, Ibitoye MB. Understanding the role of educational interventions on medication adherence in hypertension: A systematic review and meta-analysis. Heart Lung. 2020;49(5):537-47. https://doi.org/10.1016/j. hrtlng.2020.02.039

PMid:32127208

3. Krousel-Wood M, Muntner $\mathrm{P}$, Carson A, Anderson $\mathrm{AH}$, Delaune E, Cushman WC, et al. Hypertension control among newly treated patients before and after publication of the main ALLHAT results and JNC 7 guidelines. J Clin Hypertens (Greenwich). 2012;14(5):277-83. https://doi. org/10.1111/j.1751-7176.2012.00609.x PMid:22533653

4. James PA, Oparil S, Carter BL, Cushman WC, DennisonHimmelfarb C, Handler J, et al. 2014 evidence-based guideline for the management of high blood pressure in adults: Report from the panel members appointed to the Eighth Joint National
Committee (JNC 8). JAMA. 2014;5:311(5):507-20. https://doi. org/10.1001/jama.2013.284427

PMid:24352797

5. Saleem F, Hassali MA, Shafie AA, Atif M, UI Haq N, Aljadhey H. Disease related knowledge and quality of life: A descriptive study focusing on hypertensive population in Pakistan. South Med Rev. 2012;5(1):47-52.

PMid:23093899

6. Eshah NF, Al-Daken LI. Assessing public's knowledge about hypertension in a community-dwelling sample. J Cardiovasc Nurs. 2016;31(2):158-65. https://doi.org/10.1097/ jcn.0000000000000227

PMid:25658184

7. Erkoc SB, Isikli B, Metintas S, Kalyoncu C. Hypertension knowledge-level scale (HK-LS): A study on development, validity, and reliability. Int J Environ Res Public Health. 2012;9(3):101829. https://doi.org/10.3390/ijerph9031018 PMid:22690180

8. Jankowska-Polańska B, Uchmanowicz I, Dudek K, Mazur G Relationship between patients' knowledge and medication adherence among patients with hypertension. Patient Prefer Adherence. 2016;10:2437-47. https://doi.org/10.2147/ppa. s117269

PMid:27994443

9. Arthur JP, Mantovani MF, Ferraz MIR, Mattei AT, Kalinke LP, Corpolato RC. Translation and cross-cultural adaptation of the hypertension knowledge-level scale for use in Brazil. Rev Latin Am Enfermagem. 2018;26:e3073. https://doi. org/10.1590/1518-8345.2832.3073

10. Chatziefstratiou AA, Giakoumidakis K, Fotos NV, Baltopoulos G, Brokalaki-Pananoudaki $\mathrm{H}$. Translation and validation of the Greek version of the hypertension knowledge-level scale. J Clin Nurs. 2015;24(23-24):3417-24. https://doi.org/10.1111/ jocn.12906

PMid:26333020

11. Beaton DE, Bombardier C, Guillemin F, Ferraz MB. Guidelines for the process of cross-cultural adaptation of self-report measures. Spine (Phila Pa 1976). 2000;25(24):3186-91. https:// doi.org/10.1097/00007632-200012150-00014 PMid: 11124735

12. World Health Organization; 2018. Available from: https://www who.int/substance_abuse/research_tools/translation/en. [Last accessed on 2020 Jun 06].

13. Ernawati I, Islamiyah WR. The validity and reliability test of the Indonesian version of MGLS (Morisky, green, Levine adherence scale) questionnaire on patients with epilepsy. J Ibnu Sina. 2019;4(2):305-13. https://doi.org/10.36387/jiis.v4i2.330

14. Sharma S, Kc B, Alrasheedy AA, Kaundinnyayana A, Khanal A. Impact of community pharmacy-based educational intervention on patients with hypertension in Western Nepal. Australas Med J. 2014;7(7):304-13. https://doi.org/10.4066/amj.2014.2133 PMid:25157270

15. Sahoo D, Gosai H, Sahoo U, Harsoda JM. Awareness and practices of non-pharmacological approaches for management of hypertension in a geriatric population. Int J Med Students. 2014:2(2):54-5. https://doi.org/10.5195/ijms.2014.84

16. Nguyen TM, La Caze A, Cottrell N. What are validated selfreport adherence scales really measuring? A systematic review. Br J Clin Pharmacol. 2014:77(3):427-45. https://doi.org/10.1111/ bcp. 12194 PMid:23803249

17. Stirratt MJ, Dunbar-Jacob J, Crane HM, Simoni JM, Czajkowski S Hilliard ME, et al. Self-report measures of medication adherence behavior: Recommendations on optimal use. Transl Behav Med. 2015;5(4):470-82. https://doi.org/10.1007/s13142-015-0315-2 
PMid:26622919

18. Nadeem MK, Mari A, Iftikhar S, Khatri A, Sarwar T, Patel MJ Hypertension-related knowledge and its relationship with blood pressure control in hypertensive patients visiting a semi-private tertiary-care charity hospital in Karachi, Pakistan. Cureus. 2019;11(10):e5986. https://doi.org/10.7759/cureus.5986 PMid:31807374

19. Al Zahrani S, Eid Alosaimi M, Alamrim AA, Alotaibi M, Almatar EA, Almanea BA, et al. Association between knowledge and drug adherence in patients with hypertension in Saudi Arabia. Arch Pharma Pract. 2019;10(3):71-6.

20. Tsang S, Royse CF, Terkawi AS. Guidelines for developing, translating, and validating a questionnaire in perioperative and pain medicine. Saudi J Anaesth. 2017;11(Suppl 1):S80-9. https://doi.org/10.4103/sja.sja_203_17

PMid:28616007

21. Van Bloemendaal M, Bout W, Bus SA, Nollet F, Geurts AC,
Beelen A. Validity and reproducibility of the functional gait assessment in persons after stroke. Clin Rehabil. 2019;33(1):94103. https://doi.org/10.1177/0269215518791000 PMid:30084264.

22. Mehdizadeh M, Fereshtehnejad SM, Goudarzi S, Moshtagh A, Nasrabadi FD, Habibi SA, et al. Validity and reliability of shortform mcgill pain questionnaire-2 (SF-MPQ-2) in Iranian people with Parkinson's disease. Parkinsons Dis. 2020;2020:2793945. https://doi.org/10.1155/2020/2793945

PMid:32908666

23. Pramestutie HR, Silviana N. The knowledge level of hypertension patients for drug therapy in the primary health care of Malang. Indones J Clin Pharm. 2016;5(1):26-34. https://doi. org/10.15416/ijcp.2016.5.1.26

24. Putri NH, Isfandiari MA. Average blood sugar and diabetus mellitus Type II management analysis. J Berkala Epidemiol. 2013:1(2):234-43. 